\title{
Knowledge and Attitude towards Sexual and Reproductive Health Rights and Associated Factors among High School Students in Machakel District,Northwest Ethiopia
}

\author{
Wassachew Ashebir ( $\nabla$ ashebirwase@gmail.com ) \\ Debremarkos https://orcid.org/0000-0003-1976-9250 \\ Mengistu Tadesse \\ Debre Markos University \\ Belete Yimer \\ Debre Markos University
}

\section{Research}

Keywords: Knowledge, Attitude, Sexual and reproductive health rights, Students, Ethiopia

Posted Date: February 17th, 2020

DOl: https://doi.org/10.21203/rs.2.23642/v1

License: (c) (1) This work is licensed under a Creative Commons Attribution 4.0 International License.

Read Full License 
Knowledge and Attitude towards Sexual and Reproductive Health Rights and Associated Factors among High School Students in Machakel District, Northwest Ethiopia

Wassachew Ashebir ${ }^{1 *}$, Mengistu Tadesse ${ }^{2}$, Belete Yimer $^{3}$

*Corresponding Author: Wassachew Ashebir, College of Medicine and Health Sciences, Debre Markos University, P.O. Box 269, Debre Markos, Ethiopia. E-mail: ashebirwase@gmail.com

\begin{abstract}
Background: Young people have the right to make choices regarding their own sexuality, as far as they respect the rights of others. To do this, the knowledge of those rights and positive attitude in exercising these rights is critical to youth's ability to protect them from unwanted reproductive outcomes. However, many young people do not have the information or means to protect themselves from these problems. Therefore, this study aimed to assess knowledge and attitude towards Sexual and Reproductive Health (SRH) rights and associated factors among high school students in Machakel District.
\end{abstract}

Methods: School based cross sectional study was employed among 421 high school adolescents in Machakel District from March16-20/2019. Stratified sampling technique was used to select study participants. Data was collected through structured self-administered questionnaires. Data processing was done using Epi Data version 3.1then transferred to SPSS version 20 software. Bivariate \& multivariate logistic regression was done to assess the association of factors with student's knowledge and attitude towards SRH rights by calculating odds ratios, their 95\% confidence limits and P-value less than 5\% were taken as statistically significant.

Results: Overall, more than half (55.9\%) of students were found to be knowledgeable and $46 \%$ had favorable attitude towards SRH rights. Knowledge among high school students was significantly associated with being female ( $\mathrm{AOR}=0.52,95 \% \mathrm{CI}=0.33,0.81$ ), urban resident $(\mathrm{AOR}=3.43,95 \% \mathrm{CI}=1.99,5.93)$, being in grade ten $(\mathrm{AOR}=1.67,95 \% \mathrm{CI}=1.08,2.58)$, participation in $\mathrm{RH}$ clubs $(\mathrm{AOR}=2.18,95 \% \mathrm{CI}=1.37,3.47)$, discussion of $\mathrm{SRH}$ issues with parents $(\mathrm{AOR}=2.62,95 \% \mathrm{CI}=1.58,4.33)$ and with friends $(\mathrm{AOR}=1.77,95 \% \mathrm{CI}=1.15,2.74)$ while getting information on $\mathrm{SRH}(\mathrm{TV} / \mathrm{Radio})(\mathrm{AOR}=1.61,95 \% \mathrm{CI}=1.02,2.54)$ and had access to reproductive health services $(\mathrm{AOR}=3.00,95 \% \mathrm{CI}=1.30,6.90)$ were significantly associated factors with favorable attitude towards SRH rights.

Conclusions: The level of student's knowledge and attitude towards SRH rights were found to be low. Being female, urban resident, being in grade ten, participation in RH clubs, and discussion of SRH issues with parents and friends had significant association with knowledge while getting information on reproductive health and had access to reproductive health services with favorable attitude towards SRH rights. Hence, encouraging discussions with parents and participation in RH clubs may improve the knowledge and attitude of students on SRH rights. Keywords: Knowledge, Attitude, Sexual and reproductive health rights, Students, Ethiopia 


\section{Plain English summary}

The aim of this study was to assess knowledge and attitude towards SRH rights and associated factors among high school students. Understanding student's knowledge and attitude towards SRH rights is important to look for the unique health needs of such students and their right to access and use SRH services. Four hundred twenty one high school students in Machakel District, Northwest Ethiopia were participated in this study. Self-administered questionnaire was used to measure the main variables of socio-demographic characteristics of students, student's knowledge and attitude of sexual and reproductive rights and their source of information and discussion with other person. The results suggest that more than half (55.9\%) of students were found to be knowledgeable and $46 \%$ had favorable attitude towards SRH rights. Knowledge among high school students was significantly associated with being female, urban resident, being in grade ten, participation in RH clubs, discussion of SRH issues with parents and with friends while getting information on SRH(TV/Radio) and had access to reproductive health services were significantly associated factors with favorable attitude towards SRH rights. Therefore, it is essential to address these important factors with integrated education and communication interventions to protect students from unwanted reproductive outcomes.

\section{Background}

Sexual and reproductive health rights (SRHR) refers the right for all people, regardless of age, gender and other characteristics, to make choices regarding their own sexuality and reproduction, provided that they respect the rights of others. SRH rights therefore include access to SRH care services, such as information relating to sexuality, sexuality education, respect for bodily integrity, choosing own partner, deciding to be sexually active or not, consensual sexual relations and marriage, decision whether or not and when to have children and pursuing a satisfying and pleasurable sexual life $(1,2)$.

According to the International Conference on Population and Development (ICPD) Program of Action, addressing the sexual and reproductive health needs of young people in particular is a very critical requirement for human and social development since announcing and exercising the sexual and reproductive rights of the youth and empowering them to make informed choices is relevant to their wellbeing (3). Despite such importance, the needs of SRH services for young people were not well understood in many parts of the world. As a result, young people face increasing pressures from early and unplanned sex and rates of sexual activity with contradictory messages and norms. This may be facilitated by lack of understanding about their rights and results in SRH problems that many young people being either fail to seek help when they need it or are unable to deal with such violations because of barriers like because of their inadequate knowledge and experience on sexuality issues $(4,5)$.

Worldwide, adolescent sexual and reproductive health remains a challenge. More than half of the women who ever had an intimate partner reporting physical and/or sexual domestic violence, Sixteen million births worldwide, 111 million cases of sexually transmitted infections and $15 \%$ 
of new adult Human Immunodeficiency Virus (HIV) cases, occur among adolescents (6-8). In this regard, high prevalence of unwanted pregnancies, forced childbearing, Sexually Transmitted Infections (STI's), HIV, and unsafe abortions that depict lack of knowledge about sexuality and reproductive health among adolescents are noted worldwide (9). As a result of lack of access, demand and knowledge about SRH services among sexually active adolescent girls, about 50\% of adolescents (15-19) gave birth in most countries (10).

Studies done in Ethiopia also showed that there was $42.1 \%$ sexual risk behavior, $19 \%$ of youths reported having had premarital sexual intercourse with the mean age of 16.48 years at the first sexual intercourse, self-reported STIs prevalence was $19.5 \%$ and abortion rate was also 65 per 1000 women(11, 12, 13,14). Even though the comprehensive knowledge of HIV and other Reproductive Health ( $\mathrm{RH})$ problems is increasing around the world, many young people do not have the information or means to protect themselves from these problems (15). The new Sustainable Development Goals agenda reflects the importance of youth citizenship, autonomy, rights and active and healthy engagement in society as core youth development aspects. Yet, despite governmental efforts, the health and wellbeing needs of many adolescents are not being fulfilled (16).

Evidences indicated that there is a discrepancy between knowledge, services utilization and access to RH services $(17,18)$. Studies in Nigeria revealed that the majority of the adolescents $60.3 \%$ in Ikeja and $62.3 \%$ in Ikorodu were aware of SRH rights (19). In relation to this, RH needs of the adolescents and their right to access them have been neither researched nor addressed adequately, but limited studies in Ethiopia indicated that knowledge of participants about SRH issues varies from 31.6 to $67 \%$ (20-24). In a study conducted at southern Ethiopia, $45.5 \%$ of students lack knowledge about SRH rights, and $80 \%$ do not know the reproductive health services $(25,26)$.

Many factors affect reproductive health, and its attainment is not limited to interventions by the health sector alone. Reproductive health is affected by, the broader context of people's lives, including their economic circumstances, education, employment, living conditions and family environment, social and gender relationships, and the traditional and legal structures within which they live. Among others, knowledge about SRHRs and RH service are affected by negative behaviors and attitudes of healthcare workers, sex taboos and SRH service related factors such as cost, providers attitude and confidentiality. Moreover age, residence, school attended at elementary, studying fields, prior SRH education/lectures, parental occupation and education, discussion of sexual issues with others, and source of information (27-37).

Despite all these problems and violations of rights, investigating the knowledge of young people on sexual and reproductive rights and their attitude in exercising these rights are essential. However, there were little studies assessing youth's level of knowledge and attitude towards sexual and reproductive rights. This study is therefore, aimed to assess knowledge and attitude towards SRH rights and associated factors among Machakel district high school students. 


\section{Methods}

\section{Study setting, population and design}

Institutional based cross sectional study was employed among 421 high school students in Machakel District from March16-20/2019. Machakel District had four high schools namely Degasegnen high school, Shelel high school, Girakidamin high school and Amanuel high school.. According to the District Education office data, the total number of the source population was 4,110 students (male, 2001 and females, 2109). The study participants were randomly selected high school adolescent students aged 10 to 19 years.

\section{Sample size and sampling procedure}

Sample size was determined by using single population proportion formula with the assumption of 53\% proportion of knowledgeable students about SRH rights (38), confidence interval of $95 \%$, margin of error of $5 \%$ and none response rate of $10 \%$. Therefore, the final sample size was 421. Following sample size determination, the students were stratified into grade nine and grade 10 based on their grade level. All these high schools were included in the study. The sample was then proportionally allocated to each high school based on the number of students. Finally, the simple random sampling technique was used to select study participants from each grade level and section based on their attendance lists.

\section{Data collection}

A self-administered structured questionnaire was used to collect data. The questionnaire was developed based on the conceptual framework through reviewing of different literatures and it covered a range of information on socioeconomic and demographic characteristics, knowledge of reproductive rights, attitude towards reproductive rights and source of information and discussion with other person. The questionnaire first prepared in English was translated to Amharic and translated back to English in order to maintain its consistency. A total of eight data collectors with diploma holder nurses and two BSc holder supervisors were recruited for data collection. Data quality was checked during questionnaire designing, data collection, and data entry. The collection questionnaire was pre-tested among 5\% of study subjects to the neighboring district (Gozamin district). The data collectors and supervisors were trained at district town (Amanuel) for one day on the objectives of the study and data quality to minimize inter-individual variability (measurement of precision and accuracy of each trainer were calculated and maintained during the training session).

\section{Measurements}

The outcome variable of interest in this study, knowledge and attitude towards SRHR were measured based on respondents self-report. Accordingly, Knowledge about SRH rights, the dependent variable, was measured by using 18 questions and each question contains $-0=$ No 
and $-1=$ Yes alternatives. As a result, the total score was $(0-18)$ and participants who scored above the mean score were considered as knowledgeable. On the other hand, attitude towards SRH rights was also measured by using 10 questions and each question contains $-0=$ disagreell and $-1=$ agree $\|$ alternatives. As a result, the total score was $(0-10)$ and participants who scored above the mean score was considered as having favorable attitude towards SRH rights. The reliability of knowledge and attitude measuring items were checked by calculating the Cronbach alpha $(\alpha)$. The Cronbach alpha $(\alpha)$ for knowledge and attitude measuring tools were 0.81 and 0.83 , respectively. Statistical analysis

Data were cleaned and analyzed using SPSS version 20. Descriptive summary (Frequency distribution, mean \& standard deviation) were used to summarize the variable. A binary logistic regression model was used to investigate factors associated with knowledge and attitude towards SRHR. Variables with a p values of $<0.2$ in the bivariate analysis were entered in to the multivariable analysis to control the possible effect of confounders. The adjusted odds ratio (AOR) with a $95 \%$ confidence interval was used to assess the strength of association and a $\mathrm{p}$ value of $<0.05$ was used to declare the statistical significance in the multivariable analysis.

\section{Results}

\section{Socio- demographic characteristics of respondents}

A total of 415 students participated in the study with a response rate of $98.57 \%$. The mean age of the participants was $17 \pm 1.51$ years. The majority of the respondents $(91.8 \%)$ were in the age of $15-19$.Nearly $95 \%$ of the participants were Orthodox Christians.More than half $(53.5 \%)$ of the participants were grade 9 students. Most (75.4\%) of the respondents came from rural areas and more than ninety percent $(91.3 \%)$ of them were single. Their parents' demographic data showed that $63.6 \%$ of their fathers and $57.6 \%$ of their mothers were farmers (Table1)

Table 1 Socio demographic characteristics of Machakel high school students Northwest Ethiopia, 2019 (N=415)

\begin{tabular}{|l|l|l|l|}
\hline Variable & Category & Frequency & Percentage (\%) \\
\hline \multirow{3}{*}{ Age } & $15-19$ & 381 & 91.8 \\
\cline { 2 - 4 } & $20-23$ & 34 & 8.2 \\
\hline \multirow{2}{*}{ rex } & Male & 239 & 57.6 \\
\cline { 2 - 4 } & Female & 176 & 42.4 \\
\hline \multirow{2}{*}{ Marital status } & Orthodox & 393 & 94.7 \\
\cline { 2 - 4 } & Muslim & 22 & 5.3 \\
\hline \multirow{2}{*}{ Residence } & Single & 379 & 91.3 \\
\cline { 2 - 4 } & Married & 36 & 8.7 \\
\hline & Urban & 102 & 24.6 \\
\cline { 2 - 4 } & Rural & 313 & 75.4 \\
\hline
\end{tabular}




\begin{tabular}{|l|l|l|l|}
\hline Grade & Grade nine & 222 & 53.5 \\
\cline { 2 - 4 } & Grade ten & 193 & 46.5 \\
\hline \multirow{5}{*}{ Father occupation } & Government employee & 39 & 9.4 \\
\cline { 2 - 4 } & Private employee & 28 & 6.7 \\
\cline { 2 - 4 } & Merchants & 84 & 20.2 \\
\cline { 2 - 4 } & Farmer & 264 & 63.6 \\
\hline Mother occupation & House wife & 148 & 35.7 \\
\cline { 2 - 4 } & Government employee & 28 & 6.7 \\
\cline { 2 - 4 } & Farmer & 239 & 57.6 \\
\hline
\end{tabular}

Knowledge and attitude towards SRH Rights

Participants were asked 18 questions to assess their knowledge and 10 questions to assess their attitude towards reproductive and sexual rights, and they were categorized in to two groups based on their score in relation to the mean. This study revealed that $55.9 \%$ of the participants were knowledgeable about SRH rights and less than half (46\%) of the students had favorable attitude towards SRH rights

In relation to respondents knowledge towards SRH rights, about two hundred-thirty five $(56.6 \%)$ of the respondents did not support the idea that families have the right to decide on their female child marriage. Nearly two third $(68 \%)$ of the respondents said that youths have right of their own mate selection without their family approval. In this study, 281(67.7\%) of respondents agree on confidentiality of reproductive health services while less than thirty-two percent of the respondents do not agree with confidentiality of reproductive health services. Two hundred eighteen $(52.5 \%)$ of the study participants said that a husband should get sex whenever he wants while one hundred ninety seven $(47.5 \%)$ of the respondents agree on the refusal of woman to have sex regardless of her husband's wishes.

Regarding respondents attitude towards SRH rights, one hundred eighty seven $(45.1 \%)$ of the study participants agree that a husband should get sex whenever he wants irrespective of his wife's wish. 155 (37.3\%) agreed with the question that reflected the right of girls to autonomous reproductive choices without their partners` consent. One hundred eighty three $(44.1 \%)$ disagreed with parents have the right to decide on sexual and $\mathrm{RH}$ issues of their children. One hundred eighty (43.4\%) agreed with the statement that unmarried couples have no right to use contraceptives other than condom.

\section{Factors associated with knowledge of SRH rights}

Sex, grade level, place they came from, participation in RH clubs, discussion of RH issues with parents, and discussion of RH issues with friends were found to have significant and independent effect on knowledge of reproductive and sexual rights. 
The odds of being knowledgeable about SRH rights among female student was decreased by $48 \%(\mathrm{AOR}=0.52,95 \% \mathrm{CI}=0.33,0.81)$ when compared with male students. Study participants who were in grade ten were about 1.6 times more likely to be knowledgeable than students at grade nine level $(\mathrm{AOR}=1.67,95 \% \mathrm{CI}=1.08,2.58)$. Students who came from urban area were 3.43 times more likely to be knowledgeable than those from rural areas (AOR=3.43, 95\% CI=1.99, 5.93). Respondents who participate in RH clubs were about 2 times more likely to be knowledgeable than those who did not participate(AOR=2.18, 95\% $\mathrm{CI}=1.37,3.47)$. Students who ever had discussed $\mathrm{RH}$ issues with parents were 2.6 times more likely to be knowledgeable than those who did $\operatorname{not}(\mathrm{AOR}=2.62,95 \% \mathrm{CI}=1.58,4.33)$. Students who ever had discussed $\mathrm{RH}$ issues with friends were 1.77 times more likely to be knowledgeable than those who did $\operatorname{not}(\mathrm{AOR}=1.77,95 \% \mathrm{CI}=1.15,2.74)$ (Table 2)

Table 2Factors associated with knowledge of SRH rights among Machakel high school students Northwest Ethiopia, 2019 ( $N=415)$

\begin{tabular}{|c|c|c|c|c|}
\hline \multirow[t]{2}{*}{ Variables } & \multicolumn{2}{|c|}{ Knowledge onSRHR } & \multicolumn{2}{|l|}{ Odds ratio(OR) } \\
\hline & $\begin{array}{l}\text { Knowledgea } \\
\text { ble }\end{array}$ & $\begin{array}{l}\text { Not } \\
\text { Knowledg } \\
\text { eable }\end{array}$ & $\operatorname{COR}(95 \% \mathrm{CI})$ & $\operatorname{AOR}(95 \% \mathrm{CI})$ \\
\hline $\begin{array}{l}\text { Sex } \\
\text { Male } \\
\text { Female }\end{array}$ & $\begin{array}{l}148 \\
84\end{array}$ & $\begin{array}{l}85 \\
88\end{array}$ & $\begin{array}{l}1 \\
0.56(0.37,0.83)^{*}\end{array}$ & $\begin{array}{l}1 \\
0.52(0.33,0.81)^{* * *}\end{array}$ \\
\hline $\begin{array}{l}\text { Religion } \\
\text { Orthodox } \\
\text { Muslim }\end{array}$ & $\begin{array}{l}224 \\
8\end{array}$ & $\begin{array}{l}169 \\
14\end{array}$ & $\begin{array}{l}2.32(0.95,5.65) \\
1\end{array}$ & $\begin{array}{l}1.59(0.58,4.33) \\
1\end{array}$ \\
\hline $\begin{array}{l}\text { Grade } \\
\text { Nine } \\
\text { Ten }\end{array}$ & $\begin{array}{l}114 \\
118\end{array}$ & $\begin{array}{l}108 \\
75\end{array}$ & $\begin{array}{l}1 \\
1.491(1.00,2.20)\end{array}$ & $\begin{array}{l}1 \\
1.67(1.08,2.58)^{* * *}\end{array}$ \\
\hline $\begin{array}{l}\text { Residence } \\
\text { Urban } \\
\text { Rural }\end{array}$ & $\begin{array}{l}154 \\
78\end{array}$ & $\begin{array}{l}159 \\
24\end{array}$ & $\begin{array}{l}3.33(2.01,5.57) \\
1\end{array}$ & $\begin{array}{l}3.43(1.99,5.93) * * \\
1\end{array}$ \\
\hline $\begin{array}{l}\text { Father education } \\
\text { Illiterate } \\
\text { Elementary school } \\
\text { Secondary school } \\
\text { Collage and above }\end{array}$ & $\begin{array}{l}107 \\
55 \\
38 \\
32\end{array}$ & $\begin{array}{l}112 \\
40 \\
18 \\
13\end{array}$ & $\begin{array}{l}1 \\
1.43(0.88,2.34) \\
2.21(1.18,4.10)^{*} \\
2.57(1.28,5.17)^{* *}\end{array}$ & $\begin{array}{l}1 \\
1.10(0.62,1.96) \\
1.74(0.82,3.69) \\
3.77(0.88,16.00)\end{array}$ \\
\hline $\begin{array}{l}\text { Mother education } \\
\text { Illiterate } \\
\text { Elementary school } \\
\text { Secondary school } \\
\text { Collage and above }\end{array}$ & $\begin{array}{l}139 \\
51 \\
19 \\
23\end{array}$ & $\begin{array}{l}126 \\
33 \\
11 \\
13\end{array}$ & $\begin{array}{l}1 \\
1.40(0.85,2.30) \\
1.56(0.71,3.41) \\
1.60(0.77,5.30)\end{array}$ & $\begin{array}{l}1 \\
1.00(0.53,1.89) \\
0.95(0.36,2.47) \\
0.39(0.09,1.60)\end{array}$ \\
\hline
\end{tabular}




\begin{tabular}{|c|c|c|c|c|}
\hline $\begin{array}{l}\text { Father occupation } \\
\text { Government employed } \\
\text { Private } \\
\text { Merchant } \\
\text { Farmer }\end{array}$ & $\begin{array}{l}25 \\
17 \\
57 \\
133\end{array}$ & $\begin{array}{l}14 \\
11 \\
27 \\
131\end{array}$ & $\begin{array}{l}1.75(0.87,3.53) \\
1.52(0.68,3.37) \\
2.07(1.23,3.48)^{* *} \\
1\end{array}$ & $\begin{array}{l}0.31(0.09,1.02) \\
0.08(0.34,2.23) \\
0.42(0.18,1.21)^{*} \\
1\end{array}$ \\
\hline $\begin{array}{l}\text { Mother occupation } \\
\text { House wife } \\
\text { Government employed } \\
\text { Farmer }\end{array}$ & $\begin{array}{l}100 \\
20 \\
112\end{array}$ & $\begin{array}{l}48 \\
8 \\
127\end{array}$ & $\begin{array}{l}2.36(1.54,3.62)^{* *} \\
2.83(1.20,6.68)^{*} \\
1\end{array}$ & $\begin{array}{l}1.67(0.02,2.73)^{*} \\
1.17(0.41,3.26) \\
1\end{array}$ \\
\hline $\begin{array}{l}\text { Assembly and political participation } \\
\text { Yes } \\
\text { No }\end{array}$ & $\begin{array}{l}149 \\
83\end{array}$ & $\begin{array}{l}138 \\
45\end{array}$ & $\begin{array}{l}0.58(0.38,0.90)^{*} \\
1\end{array}$ & $\begin{array}{l}0.90(0.55,1.47) \\
1\end{array}$ \\
\hline $\begin{array}{l}\text { SRH discussion with anyone else } \\
\text { Yes } \\
\text { No }\end{array}$ & $\begin{array}{l}189 \\
43\end{array}$ & $\begin{array}{l}130 \\
53\end{array}$ & $\begin{array}{l}1.792(1.31,2.839)^{*} \\
1\end{array}$ & $\begin{array}{l}1.65(0.99,2.75) \\
1\end{array}$ \\
\hline $\begin{array}{l}\text { Participation in RH club } \\
\text { Yes } \\
\text { No }\end{array}$ & $\begin{array}{l}176 \\
56\end{array}$ & $\begin{array}{l}106 \\
77\end{array}$ & $\begin{array}{l}2.28(1.50,3.47)^{* *} \\
1\end{array}$ & $\begin{array}{l}2.18(1.37,3.47)^{* * *} \\
1\end{array}$ \\
\hline $\begin{array}{l}\text { SRH discussion with friends } \\
\text { Yes } \\
\text { No }\end{array}$ & $\begin{array}{l}134 \\
98\end{array}$ & $\begin{array}{l}79 \\
104\end{array}$ & $\begin{array}{l}1.80(1.21,2.66)^{* *} \\
1\end{array}$ & $\begin{array}{l}1.77(1.15,2.74) * \\
1\end{array}$ \\
\hline $\begin{array}{l}\text { SRH discussion with parents } \\
\text { Yes } \\
\text { No }\end{array}$ & $\begin{array}{l}193 \\
39\end{array}$ & $\begin{array}{l}117 \\
66\end{array}$ & $\begin{array}{l}2.79(1.76,4.41) * * \\
1\end{array}$ & $\begin{array}{l}2.62(1.58,4.33) * * \\
1\end{array}$ \\
\hline $\begin{array}{l}\text { Get information on SRH? } \\
\text { TV/Radio } \\
\text { Newspaper } \\
\text { Teacher } \\
\end{array}$ & $\begin{array}{l}132 \\
31 \\
69\end{array}$ & $\begin{array}{l}101 \\
19 \\
63\end{array}$ & $\begin{array}{l}1.19(0.77,1.83) \\
1.49(0.76,2.89) \\
1\end{array}$ & $\begin{array}{l}1.02(0.61,1.73) \\
1.63(0.76,3.47) \\
1\end{array}$ \\
\hline
\end{tabular}

NB: $\mathrm{COR}=$ Crude odds ratio, AOR=Adjusted odds ratio*p-value $<0.05$, **p-value $<0.01$

\section{Factors associated with attitude towards SRH rights}

In this study, students who get information from TV/Radio were 1.6 times more likely to had favorable attitude than others(AOR=1.61, 95\% CI=1.02, 2.54). Respondents who had access to reproductive health services were 3 times more likely to had favorable attitude than who didn't have access to reproductive health services(AOR=3.00, 95\% CI=1.30, 6.90) (Table 3).

Table 3 Factors associated with attitude towards SRH rights among Machakel high school students Northwest Ethiopia, 2019 ( $N=415)$ 


\begin{tabular}{|c|c|c|c|c|}
\hline & $\begin{array}{l}\text { favorable } \\
\text { Attitude }\end{array}$ & \begin{tabular}{|l|} 
Unfavorable \\
Attitude \\
\end{tabular} & $\operatorname{COR}(95 \% \mathrm{CI})$ & $\operatorname{AOR}(95 \% \mathrm{CI})$ \\
\hline \multicolumn{5}{|l|}{ Sex } \\
\hline Male & 95 & 125 & 1 & 1 \\
\hline Female & 96 & 99 & $1.27(1.235,5.697)^{*}$ & $1.42(0.94,2.13)$ \\
\hline \multicolumn{5}{|l|}{ Religion } \\
\hline Orthodox & 184 & 209 & $1.88(0.75,4.72)^{*}$ & $1.18(0.44,3.177)$ \\
\hline Muslim & 7 & 15 & 1 & 1 \\
\hline \multicolumn{5}{|l|}{ Residence } \\
\hline Rural & 139 & 174 & 1 & 1 \\
\hline Urban & 52 & 50 & $1.30(0.83,2.03)^{*}$ & $1.41(0.93,2.15)$ \\
\hline \multicolumn{5}{|l|}{ Marital status } \\
\hline Single & 12 & 24 & $1.79(0.87,3.68)^{*}$ & $2.04(0.95,2.13)$ \\
\hline Married & 179 & 200 & 1 & 1 \\
\hline \multicolumn{5}{|l|}{ Mother education } \\
\hline Illiterate & 113 & 152 & 1 & 1 \\
\hline Elementary school & 45 & 39 & $1.55(0.94,2.54)^{*}$ & $1.50(0.87,2.59)$ \\
\hline Secondary school & 14 & 16 & $1.17(0.55,2.51)$ & $1.35(0.59,3.10)$ \\
\hline Collage and above & 19 & 17 & $1.50(0.74,3.02)$ & $1.13(0.45,2.85)$ \\
\hline \multicolumn{5}{|l|}{ Father occupation } \\
\hline Government employed & 23 & 16 & $1.72(0.87,3.41)^{*}$ & $1.59(0.78,3.23)$ \\
\hline Private & 14 & 14 & $1.20(0.55,2.61)$ & $0.92(0.40,2.10)$ \\
\hline Trader & 34 & 50 & $0.81(0.49,1.34)$ & $0.81(0.48,1.37)$ \\
\hline Farmer & 120 & 144 & 1 & 1 \\
\hline \multicolumn{5}{|l|}{ Access to SRH services } \\
\hline Yes & 183 & 198 & $3.00(1.32,6.80)^{* *}$ & $3.00(1.30,6.90) *$ \\
\hline No & 33 & 26 & 1 & 1 \\
\hline \multicolumn{5}{|l|}{ SRH discussion with anyone else } \\
\hline $\begin{array}{l}\text { Yes } \\
\text { No }\end{array}$ & $\begin{array}{l}158 \\
33\end{array}$ & $\begin{array}{l}161 \\
63\end{array}$ & $\begin{array}{l}1.87(1.32,3.00)^{*} \\
1\end{array}$ & $\begin{array}{l}1.64(0.01,2.68) \\
1\end{array}$ \\
\hline \multicolumn{5}{|l|}{ Get information on SRH } \\
\hline TV/Radio & 118 & 115 & $1.57(1.02,2.43)^{*}$ & $1.61(1.02,2.54) *$ \\
\hline News paper & 21 & 29 & $1.11(0.57,2.15)$ & $1.12(0.57,2.20)$ \\
\hline Teachers & 52 & 80 & 1 & 1 \\
\hline
\end{tabular}

\section{Discussion}

This study was tried to assess knowledge and attitude towards sexual and reproductive health rights with associated factors among Machakel high school students. This study found that 
$55.9 \%$ of the respondents were knowledgeable about sexual and reproductive health rights. The finding was in line with studies conducted in Ambo (59.6\%) (20) and Adet Tana Haik (54.5\%) (38). However, the result was lower than those of studies conducted in East Gojjam, Ethiopia (67\%) (21) And Asella town, Ethiopia which was 70\% (34), but higher than those of studies in Harar (31.6\%) (24) and Shire town (47.1\%) (22). On the other hand, in this study less than half $(46 \%)$ of the participants had favorable attitude towards SRH rights. This finding was lower than the study conducted in Adet Tana Haik (53.4\%) (38). This variation might be due to the differences in study population, area and period.

The study showed that female students were less likely to be knowledgeable than male counterparts. This finding was also supported by the study conducted in Adet Tana Haik (38). This might be due to females not participating in RH clubs as males do. The study demonstrated that students who came from urban areas were more likely to be knowledgeable when compared to those who came from rural areas. This finding was also agreed by the study conducted in Ambo (39). The possible explanation for this can be students from towns are relatively near to information through youth associations, youth centers, media and the environment itself because most of NGOs services are limited to urban areas. In contrary, as evidenced from the Ethiopian demographic and health survey people from rural areas are less likely to read a newspaper, listened to the radio, or watched television; therefore their knowledge about SRHRs can be negatively affected.

The study showed that grade ten students were more likely to be knowledgeable than grade nine. This finding was supported by studies conducted at Wolaita Sodo University (13) and East Gojjam zone (21). This might be the result of the deference's in exposure, information sharing and communication on SRH rights among students in the senior classes. The study revealed that students who participated in RH clubs were more than 2 times more likely to be knowledgeable than their counter-parts. This finding was in line with those of studies done at Wolaita Sodo University (13) and Shire town, Ethiopia (22). This might be because students who had participated in RH clubs might have the opportunity to ask and discuss about SRH rights.

The study demonstrates that students who had discussed SRH issues with their parents were more likely to be knowledgeable than students who did not discussed. This study was also consistent with studies conducted at Wolaita Sodo University and East Gojjam zone, Ethiopia $(13,21)$. The possible explanation might be might be due to parents may share their experiences during discussion and expertise, particularly proper parental guidance on some of the genesis of SRH problems experienced in young people would help the participants to have good knowledge. Students who have ever had discussed RH issues with friends were more likely to be knowledgeable than those who did not. This can be explained by the fact that knowledge gained through experience sharing during discussion can increase the knowledge of reproductive and sexual rights. 
Our findings also indicated that students who got information on reproductive health from TV/Radio were more likely to had favorable attitude than students did not. This result was supported by study done in Jimma town (39). The possible justification might be due to students who watch TV and listen radio might analyze and understand the risks/benefits and they might have good initiation to exercise their theoretical knowledge into practice. The study demonstrates that youths who had access to information on reproductive health services were more likely to had favorable attitude than who didn't had access to reproductive health services. The probable reason could be in these service settings students are more likely to get education about SRHRs while they visit the health facilities for other RH services which boosts their knowledge.

\section{Conclusions}

Based on the findings of the research, it is concluded that the level of knowledge and attitude towards sexual and reproductive health rights were low.

Sex, grade level, place they came from, participation in RH clubs, discussion of RH issues with parents, and discussion of RH issues with friends were found to have significant and independent effect on knowledge of reproductive and sexual rights while access to SRH service and getting information about SRH issues from TV and radio were factors significantly associated with favorable attitude towards SRH rights.

\section{Recommendations}

Encouraging discussions with parents and participations in reproductive health clubs at school levels might improve the knowledge and attitude towards SRH rights. Emphasis on more mass media TV/radio coverage especially on newspapers and leaf late regarding Sexual and Reproductive Health rights to create more awareness. Incorporate sexuality education which has reproductive and sexual rights in to the curriculum of elementary and high schools institutions. Families should get information about SRHR and have an open discussion with their children regarding sexual and reproductive health right and issues.

\section{Conflicts of Interest}

The authors did not receive payments, funding, or salary from any organization in relation to the work and publication of this paper in the past five years and there will also be no financial support to be received in the future. There is not any organization affected positively or negatively by the publication of this paper. There are not any competing interests related with patents of the content of the paper. The authors also declare that there are not any other financial or nonfinancial competing interests.

\section{Availability of data and materials}

Data will be available upon request of the corresponding authors 


\section{Funding}

No fund is obtained for this study

\section{Authors' Contribution}

All authors, Wassachew Ashebir, Mengistu Tadesse and Belete Yimer conceptualized the research question, monitored and managed fieldwork, analyzed and interpreted the findings, and written the paper.

\section{Consent for publication}

Not applicable

\section{Ethical approval and consent to participate}

Ethical clearance was obtained from the Ethical Review Committee of College Of Health Science, Debre Markos University. After the objective of the study was explained, verbal consent was obtained from school administrators and each participant. Moreover, privacy and confidentiality of information was strictly guaranteed by all data collectors and investigators. Male and female students were interviewed separately to keep their confidentiality.

\section{Acknowledgment}

DebreMarkos University provided opportunity and other supports for this research project. The authors are grateful to high school adolescents who sacrificed their time. The authors also thank the data collectors for their responsible data collection.

\section{Author details}

${ }^{1}$ Department of Public Health, College Of Health Science, Debre Markos University, Ethiopia, ${ }^{2}$ Machakel Health Office, East Gojam Zone, Ethiopia., ${ }^{3}$ Department of Human Nutrition and Food Science, College Of Health Science, Debre Markos University, Ethiopia.

\section{Abbreviations}

AOR; Adjusted odds ratio; CI; Confidence interval; COR; Crude odds ratio; HIV; Human immunodeficiency virus; ICPD; International conference on population and development; RH; Reproductive health; STI; Sexually transmitted infections; SRH; Sexual and reproductive health; TV; Television

\section{References}

1. Griffin S: Literature review on Sexual and Reproductive Health Rights: Universal Access to Services, focusing on East and Southern Africa and South Asia. Panos, London: Department for International Development; 2006.

2. Organization WH. Sexual and reproductive health. Geneva: World Health Organization; 2013. http://www.whoin t/repro ductiveehealth/topic s/ sexual_healt h/sh_definition s/en/index .html. Accessed 16 Aug 2013. 
3. Asghar K: Socio-Economic and Cultural Determinants of Attitude towards Reproductive Health Rights in Punjab. Pakistan: University of Agriculture; 2010.

4. Starrs AM, Ezeh AC, Barker G, Basu A, Bertrand JT, et al. (2018) Accelerate progresssexual and reproductive health and rights for all: report of the Guttmacher-Lancet Commission. Lancet 391: 2642-2692. Link: http://bit.ly/2ZEobXw

5. Kudolo P, Kavi E, Abdul-Rahman A. Baseline survey on adolescent sexual and reproductive health in the operational area of ten ACDEP-Member primary health care programmes in Northern and Upper East regions. Health, Association of church based development NGOs (ACDEP). 2008.

6. WHO. Displaced or refugee women are at increased risk of violence. 2018.

7. (WHO). World health statistics — monitoring health for the SDGs. . 2016.

8. UNICEF Data: Monitoring the Situation of Children and Women . Turning the tide against AIDS will require more concentrated focus on adolescents and young people. 2018.

9. Mustapa MC, Ismail KH, Mohamad MS, Ibrahim F (2015) Knowledge on Sexuality and Reproductive Health of Malaysian Adolescents - A Short Review. ElsivierProcedia Social and Behavioral Sciences 211: 221-225. Link: http://bit.ly/32aM0YA

10. Patton GC, Coffey C, Sawyer SM, Viner RM, Haller DM, et al. (2009) Global patterns of mortality in young people: a systematic analysis of population health data. Lancet 374: 881-892. Link: http://bit.ly/32iJVtZ

11. Abebe M1 TA, Netsanet F. Living with parents and risky sexual behaviors among preparatory school students in Jimma zone, South west Ethiopia. 2013.

12. Bogale A1 SA. Premarital sexual practices and its predictors among in-school youths of Shendi town, west Gojjam zone, North Western Ethiopia. 2014.

13. BereketYohannes TG, MulatTarekegn. Prevalence and Associated Factors of Sexually Transmitted Infections among Students of WolaitaSodo University, Southern Ethiopia. 2013.

14. Gelaye AA1 TK, Mekonen T. Magnitude and risk factors of abortion among regular female students in WolaitaSodo University, Ethiopia. 2014.

15. WakgariBinu TM, corresponding author2 Mulusew Gerbaba,3 and MeleseSinaga. Sexual and reproductive health services utilization and associated factors among secondary school students in Nekemte town, Ethiopia. 2018. 
16. Galati AJ (2015) Onward to 2030: Sexual and Reproductive Health and Rights in the Context of the Sustainable Development Goals. Guttmacher PolicyReview 18: 77-84. Link: http://bit.ly/2L9UBW5

17. Seifu A, Fantahun M, Worku A. Reproductive health needs of out of- school adolescents: a cross-sectional. Ethiop J Health Dev.2006;20(1):10-7.

18. FMOH: National reproductive health strategy, 2006-2015 Addis Ababa, Ethiopia. www.phe-ethio piaor g/admin //attachment -161-Natioational RH_strategy \%5B1\%5D.pdf. 2006.

19. Ogunlayi MA. An assessment of the awareness of sexual and reproductive rights among adolescents in South Western Nigeria. Afr J ReprodHealth. 2005;9:99-112.

20. Adinew YM, Worku AG, Mengesha ZB. Knowledge of reproductive and sexual rights among University students in Ethiopia: institution-basedcross-sectional. BMC Int Health Human Rights. 2013;13(1):12.

21. Abajobir AA, Seme A. Reproductive health knowledge and services utilization among rural adolescents in east Gojjam zone, Ethiopia: a community-based cross-sectional study. BMC Health Serv Res. 2014;14(1):138.

22. Gebretsadik G, Weldearegay G. Knowledge on reproductive and sexual rights and associated factors among youths, Shire town, Tigray, NorthernEthiopia. Int J Res Pharm Sci. 2016;6(2):30-7.

23. Kassa TA, Luck T, Bekele A, Riedel-Heller SG. Sexual and reproductive health of young people with disability in Ethiopia: a study on knowledge, attitude and practice: a crosssectional study. Global Health. 2016;12(1):5.

24. Motuma A, Syre T, Egata G, Kenay A. Utilization of youth friendly services and associated factors among youth in Harar town, east Ethiopia: a mixedmethod study. BMC Health Serv Res. 2016;16(1):272.

25. Yemaneh Y, Gezahagn R, Yechale M, Assefa M, Abrha K, et al. (2017) Assessment of Knowledge, Attitude and Practice Towards ReproductiveHealth Service among MizanTepiUniverstiyTepi Campus Students, ShekaZone, South Nations Nationalities and Peoples Regional State, South WestEthiopia, 2017. Journal of Hospital and Medical Management 3:11. Link:http://bit.ly/2ZynGSP

26. Jonas K, Crutzen R, Borne BVD, Reddy P (2017) Healthcare workers' behaviors and personal determinants associated with providing adequate sexual andreproductive healthcare services in sub-Saharan Africa: a systematic review.BMC Pregnancy Childbirth 17: 86. Link: http://bit.ly/2ZnE6yh 
27. Iqbal S, Zakar R, Zakar MZ, Fischer F (2017) Perceptions of adolescents' sexual and reproductive health and rights: a cross sectional study inLahore District, Pakistan. BMC Int Health Human Rights 17: 5. Link:http://bit.ly/2NF26pC

28. Tilahun M, Mengistie B, Egata G, Reda AA (2012) Health workers' attitudes toward sexual and reproductive health services for unmarried adolescents inEthiopia. Reproductive Health 9: 19. Link: http://bit.ly/2Pptryr

29. Temmerman M, Khosla R, Bhutta ZA, Bustreo F (2015) Towards a new Global Strategy for Women's, Children's and Adolescents' Health. BMJ 351. Link:http://bit.ly/30GdNjr

30. Haberland N, Rogow D (2015) Sexuality Education: Emerging Trends in Evidence and Practice. J Adolesc Health 56: 15-21. Link: http://bit.ly/2zz8F4N

31. AlQuaiz AM, Kazi A, Muneef MA (2013) Determinants of sexual health knowledge in adolescent girls in schools of Riyadh-Saudi Arabia: a crosssectional study. BMC Womens Health 13: 19. Link: http://bit.ly/2zsVH8G

32. Egemba MN, Ajuwon AJ (2015) Knowledge and Perceptions of Reproductive Rights among Female Postgraduate Students of the University of Ibadan,Nigeria. Afr J Biomed Res 18: 95 - 107. Link: http://bit.ly/2zwLxUp

33. Shiferaw K, Getahun F, Asres G (2014) Assessment of adolescents' communication on sexual and reproductive health matters with parents andassociated factors among secondary and preparatory schools' studentsin debremarkos town, North West Ethiopia. Reprod Health 11: 2. Link:http://bit.ly/34ahO1N

34. Wu Junqing, Chuanning Y, Yuyan L (2017) Effects of family planning factor on the awareness of sexual and reproductive healthcare rights amongmarried women of reproductive age in China: a cross sectional study. BMJOpen 7 . Link: http://bit.ly/2PoWx14

35. Muntean N, Kereta W, Mitchell KR (2015) Addressing the Sexual and Reproductive Health Needs of Young People in Ethiopia: An Analysis of theCurrent Situation. Afr J Reprod Health 19: 87-99. Link: http://bit.ly/2MJo5vZ

36. Gajaa M, Wakgari N, Kebede Y, Derseh L (2016) Prevalence and associated factors of circumcision among daughters of reproductive aged women inthe HababoGuduru District, Western Ethiopia: a cross-sectional study. BMCWomens Health 16: 42. Link: http://bit.ly/2MMaofJ

37. EDHS (2016) Ethiopia demographic and health survey 2016. Key indicators report. The DHS Program ICF 2016. 
38. Mulat Ayalew1, Dabere Nigatu2, and GS, Debie4 A, al. e. Knowledge and attitude towards sexual and reproductive health rights and associated factors among AdetTanaHaik College students, Northwest Ethiopia: a cross-sectional study. 2019.

39. YohannesMehretieAdinewcaAGW, and ZelalemBirhanuMengesha. Knowledge of reproductive and sexual rights among University students in Ethiopia. 2013.

40. Machakel district education office,2019. 